\title{
Digitaliseringens betydning for mennesker og samfund - er vi i stand til at balancere det gode og det onde til falles bedste?
}

\section{Teknologi ændrer mennesker på godt og ondt}

Digitaliseringen er på mange måder i gang med at forandre vores liv og vores syn på verden. Teknologi og ikke mindst digitaliseringen ser vi i dag som en afgørende ressource for fremtidens økonomiske vækst, velstand og velfærd. Heri ligger både noget godt og noget ondt. Teknologi kan på mange måder gøre vores liv lettere, erstatte arbejdskraft og øge vores viden. Men samtidigt ændrer den vores tankesæt, normer, relationer, sprog, værdier og mulighedsrum på måder, vi ikke selv kan overskue og styre. Der sker netop i disse år en ubevidst og usynlig påvirkning af vores måde at opleve og leve med teknologi på. Den ændrer grundlæggende og successivt vores måde at fungere sammen på som mennesker. Tilmed opstår et tættere samspil mellem menneskets hjerne og de anvendte teknologier, som påvirker vores identitet, tænkemåde og udsyn. Vores levevilkår bliver i dag ændret gennem alverdens teknologiske redskaber og regulativer, som skaber et sprogligt filter og en formaliseret barriere for menneskers samvær og nærhed. Teknologien er godt på vej til at ændre mennesket som art og væsen. Vore computere kan i dag udstyres med både bevidsthed og human dømmekraft, som ikke blot kan udvide, men til en vis grad også erstatte menneskehjernens sociale og refleksive funktioner. Heri ligger en fare, som vi som menneskesamfund må forholde os til. Herved opstår et globalt problem af uendelige etiske og politiske dimensioner.

\section{Teknologi er ved at tage magten i menneskesamfundet}

Her er ikke blot tale om en utopi, men om en igangværende ændring af den virkelighed, vi må forholde os til. Teknologien er blevet en magtfaktor i menneskesamfundet. Dette rejser en række grænseoverskridende etiske, æstetiske, sociale og politiske aspekter, som vi i dag ikke er i stand til at fatte, forudse, overskue og forholde os til. Der er tale om så stærke politiske og økonomiske 
kræfter, at vi som menneskesamfund næppe heller får lov til at styre og modificere udviklingen. Den sker bare ud fra nødvendighedens lov, og fordi vi lader os begejstre og forføre af de utrolige politiske fordele. Donald Trump vandt præsidentvalget, fordi det lykkedes ham via de sociale medier at bringe sine umulige ideer ud til alle de borgere, som følte sig som tabere i systemet, og som derfor ukritisk købte hans politik uden at tænke sig om.

De teknologiske fremskridt sker i disse år med en sådan hast, at hverken politikerne, medierne, samfundskritikerne, eksperterne og alle vi andre medborgere er i stand til at fatte og forholde sig til udviklingen og dens konsekvenser. Der bliver kun i begrænset omfang stillet spørgsmålstegn til, om vi skal have en grænseoverskridende digitalisering af samfundets værdier, samspil og dannelse. Det sker blot som led i samfundets politiske inerti og almindelig tankeløshed. Dermed er de basale relationer i samfundet blevet sat på tal, uanset om vi kan acceptere de åbenbare etiske, sociale og politiske aspekter heraf. Teknologiens magt udgør en kraft, som er sat udenfor samfundets og demokratiets indflydelse. Technokritikerne og de humanistiske idealer bliver simpelthen overdøvet og overhørt af teknokraternes fremtidsoptimisme og jubelkor.

\section{Der er brug for ny erkendelse af de sociale konsekvenser}

Det er derfor på sin plads at gøre rede for og skabe debat om digitaliseringens ukendte sociale og politiske konsekvenser, som vi som samfundsansvarlige medborgere bør forholde os til. Det er her vigtigt at gøre sig klart, at digitaliseringen i sig selv hverken er god eller ond. Det afhænger helt af den måde, vi som mennesker anvender teknologien til at styre og manipulere vores menneskeog samfundsliv. Det er her vigtigt at forstå den måde, vi ofte ukritisk benytter teknologien til at styrke og ensrette samfundets sociale funktioner og skabe begrænsninger for menneskers udfoldelse, frihed, samvær og lykke. Men èt er dog givet, nemlig at teknologien i alle sine forskellige former ikke er neutrale. Den kan dog endnu i et vist omfang styres af mennesker på deres præmisser, selv om vi nok må erkende, at vi er på vej mod et digitaliseret diktatur, hvor teknologien overtager styringen mod menneskers vilje. Ifald det vil ske, har vi som mennesker tabt vores identitet, værdighed og frihed. For teknologi har ikke i sig selv indbygget en etisk og æstetisk forståelse, med mindre den af mennesker bliver kodet med det. Men det er nok svært, fordi etiske og æstetiske værdier ikke lader sig hverken måle og sætte på tal. Værdier lader sig nemlig ikke digitalisere. 


\section{Mulighedsrummet er uendeligt og umuligt at få hold på}

Det er tankevækkende at se, at fremtidens teknologiske udvikling og digitaliseringens uendelige mulighedsrum på dramatisk vis vil ændre vores eksistens og vores liv på måder, som vi i dag ikke har fantasi til at forestille os. Det indebærer, at vores samfund og dets organisationer vil stå overfor store uforudsigelige forandringer, som vi næppe kan undgå eller forberede os på. Vi ser i dag, at mange teknokrater og eksperter fortæller os, at vi som mennesker og organisationer blot må leve med give efter og underkaste os digitaliseringens trusler og risici. Når de store konsulenthuse i dag gør os klart, at vi må indstille os på, at det umulige og utænkelige vil ske, har de imidlertid svært ved at komme med en modstrategi. "Disrupt (bryd op) eller dø", som det så smukt hedder. Heri ligger en eksistentiel kynisme og dødsforagt, som jo på mange måder også præger retorikken i det politiske system. Lad os for enhver pris leve op til digitaliseringens ensartede og uetiske menneskesyn, blot vi skaber vækst, velstand og velfærd. Dette er i dag et udbredt virkelighedssyn i vort samfund, som virker utroligt naivt, ufornuftigt og nærmest perverteret. Det minder os om Titanic-fortællingen med det utrolige teknologiske vidunder af et kæmpe skib, der ikke kunne synke, men som alligevel gik ned på sin første jomfrurejse. Men det var de fattige på emigranter på 3. klasse, der måtte betale med deres liv. Sådan bliver det også, når teknologien fjerner den sunde fornuft, og samfundet bryder sammen. Men paradokset er, at det er de sociale tabere, der vælger de politikere, som lover de store revolutioner, hvis de blot får magten. Her viser det sig hurtigt, at de ikke kan holde, hvad de lover. Men så er det altid for sent at reagere. For tiden kan ikke skrues tilbage. Igen ser vi de store lighedspunkter til 1930'erne.

\section{Der er brug for kritisk forskning og debat}

Der savnes i høj grad en markant og åben og folkelig debat om digitaliseringens sociale, menneskelige og politiske konsekvenser. Denne debat bliver i dag fortrængt, dels fordi vi mangler viden og forståelse for digitaliseringens ukendte konsekvenser, dels fordi videndannelsen på feltet er splittet mellem enten optimistiske teknokrater eller tvivlende humanister. Vi har i Danmark en overvægt af teknologisk optimisme, hvor der kun tales om digitaliseringens samfundsøkonomiske fordele, uden at man forholder sig til de sociale ulemper. Denne ensidighed præger mange af de centrale beslutningstagere, f.eks. centraladministrationens digitaliseringsfolk. Tilsvarende mange optimister finder vi i de politiske partier, hvor man ikke tager hensyn til befolkningens problemer med at leve under de nye og ufærdige digitaliseringsløsninger. Også i forskerverden ser vi en begrænset fokus på digitaliseringens konsekvenser, idet de fleste forskningsprojekter ikke belyser 
de sociale og etiske problemer ude i samfundet. Dette må ses som en af bivirkningerne af den tiltagende centrale styring af forskningen på feltet.

\section{Der ses bort fra de sociale og menneskelige problemer}

I 1970`erne blev der overalt i Europa gennemført en kritisk såvel teoretisk som empirisk forskning af den nye IT-teknologi og dens konsekvenser for arbejdsmiljø, trivsel, samarbejdsforhold og det lokale demokrati. Denne type forskning er i dag sjælden at finde i. I dag er IT-forskning primært rettet mod de nye muligheder for at nyttiggøre big-data til effektivisering af arbejdsprocesser, at anvende robot-teknologi til velfærdsskabelse og sygdomsbehandling, at udnytte digitale medier til undervisning etc. Forskningen er i høj grad domineret af de overordnede økonomiske samfundsproblemer og de afledte rationelle metoder og smarte teknologiske løsninger. De sociale, etiske og menneskelige problemer kommer i sidste række.

\section{Der fokuseres på hurtige og økonomiske resultater}

Dette til trods for, at en lang række IT-projekter - især i den offentlige sektor - har været fiaskoer og ikke levet op til hverken brugernes behov eller administratorernes økonomiske forventninger. Årsagerne til de ofte kostbare negative udfald af store IT-projekter forklares ofte af systemejerne og IT-folket med teknologiernes høje kompleksitet, projektledernes manglende erfaringer, medarbejdernes modstand mod forandring, brugernes utilstrækkelige uddannelse etc. Alle disse forklaringer virker utilstrækkelige og for simple i forhold til virkeligheden.

Problemerne skyldes ofte, at de valgte IT-løsninger er hastværksarbejde, der ikke tager højde for menneskers og organisationers naturlige mangfoldighed, og at virkelighedens forskellige fagkulturer og arbejdsroller bliver underkendt. Digitaliseringens ensidige funktionaliteter virker fremmedgørende og ufleksible, fordi de ofte ligger fjernt fra brugernes arbejdspraksis, faglighed, etiske ansvarlighed og menneskers naturlige behov for at kunne improvisere og tænke ud over kanten.

\section{Digitaliseringens ukendte langsigtede bivirkninger}

Vi har her alene kigget på de organisatoriske og praktiske problemer, som opstår, når mennesker skal arbejde og kommunikere digitalt. Men det er også vigtigt at pege på de skjulte etiske, sundhedsmæssige og sociale problemer, som opstår, når digitaliseringssamfundets systematik tager over og tilsidesætter basale menneskehensyn og naturgivne livsvilkår. 
Et af de store problemer er, at menneskers sundhed, hjernefunktioner og refleksionsevne i længden påvirkes af et intenst digitaliseret arbejdsmiljø. Tyske neurologer har blandt andet påvist, at børn, der allerede fra de første leveår bliver afhængig af digitale medier, har en stor tilbøjelighed til at blive demente i løbet af deres levetid. Man taler i dag om digital demens. Det er en forskning, der kun i ringe grad omtales i medierne, og som ikke tages alvorligt i den politiske debat.

Andre forskere med en sociologisk tilgang peger på, at en overdreven brug af digitale medier begrænser menneskers erkendelsesevne og gør dem mere lukkede, asociale og i høj grad påvirker deres omverdensrelationer og samfundssyn. Andre forskere peger på, at de digitale medier gør mennesker mindre kreative og rutinebelastede og er derfor lukkede overfor nye perspektiver og potentialer. Der er her tale om sociale effekter med ukendte store økonomiske konsekvenser.

\section{Alle ansvarlige borgere må påtage sig et etisk, astetisk og politisk ansvar for samfundets anvendelse af digitale medier}

Vi mener som ansvarlige forskere, samfundskritikere og medborgere, at vi langt højere grad end i dag må understøtte og mobilisere en langt mere bevidst opsøgende debat og kritisk bevidsthed om de konsekvenser, som digitaliseringen medfører. Konsekvenser, som vi i dag kun kan og tør gisne om i såvel vores faktuelle som fiktive og virtuelle forestillingsrum. Digitaliseringens globale, sociale og menneskelige problemer bør have mindst lige så stor bevågenhed som dem, vi i dag tillægger klimaproblematikken, integrationsudfordringerne og demokratiets fremtid.

Usikkerheden og uforudsigeligheden ligger på samme niveau, ligesom den sociale og politiske bevidsthed er svær at mobilisere, fordi der er tale om store globale problemer, som den enkelte har svært ved at begribe og forholde sig til, og derfor ikke føler, at man kan gøre noget ved. Denne afmagt er vor tids største demokratiske problem.

Også her ser vi store muligheder for at inddrage kunstens sprog og magt som illustrator og øjenåbner og som en samskabende kraft, der kan skabe modvægt til digitaliseringens ofte ensrettende og systemiske klaustrofobi og diktatur. Kunsten kan skabe nye kreative muligheder for menneskers frie udfoldelse, gerne med teknologien som konstruktiv kreativ medskaber, men ikke som rigid regulator. 